DOI https://doi.org/10.36059/978-966-397-186-5/69-84

\title{
MEMORY STUDY AND COMMEMORATION EFFECT OF MODERN UKRAINIAN FICTIONAL TEXTS
}

\section{Iryna Rybalka}

\section{INTRODUCTION}

In the past fifty of so years, the society has demonstrated an increasing interest in studying memory that has opened a certain epoch in this field of knowledge. Some researchers even dare to refer to this phenomenon as a "memory boom". The boom started in late 1970s in sociology and has only begun to wind down at the turn on millennium ${ }^{1}$. But the decrease of the interest to the topic among the sociologist has transformed into the "boom" of "memory study" in other humanitarian fields such as philosophy, psychology, culture studies, politics, public relation and even theory and history of literature.

The raise of interest to understanding the mechanisms of collective memory could be understood easily when taking into consideration "the decline of postwar modernist narratives of progressive improvement through an ever-expanding welfare state, nation-states turned to the past as a basis for shoring up their legitimacy. The decline of utopian visions supposedly redirected our gaze to collective pasts, which served as a repository of inspiration for repressed identities and unfulfilled claims. Without unifying collective aspirations, identity politics proliferated"2.

"Memory studies" are one of the most pressing fields of interdisciplinary research today, the main purpose of which is supposed to study the collective and cultural memory of any society. One of the most urging reason for studying it is to single out the unifying elements for the society as a group of individuals. Collective memory, that is manifested and fulfilled in traditions, beliefs and myths cultivated in society, occupied the minds of mainly historians, sociologists and psychologists until recently. The results of this kind of researching is broadly used in public relation, politics, sociology and so on. At the present day, when the relationship between different fields of knowledge becomes vaguer, this phenomenon has also interested the literary scholars. They tend to use fictional texts as a source to collect the information

\footnotetext{
${ }^{1}$ Jeffrey K. Olick, Vered Vinitzky-Seroussi, Daniel Levy (2011). The Collective Memory Reader. Oxford University. (in English) P. 3.

${ }^{2}$ Jeffrey K. Olick, Vered Vinitzky-Seroussi, Daniel Levy (2011). The Collective Memory Reader. Oxford University. (in English) P. 4
} 
about the common past as well as to treat the texts as a certain "places to memory" or a commemorative practice.

The aim of our research is to study the peculiarities of the author's literary understanding and representation of the collective memory images. We also make an attempt to analyze of the commemoration as a plot structural element of the novel "I wish" 3 by the well-known Ukrainian writer and journalist Iren Rozdobudko.

\section{Maurice Haldwachs and his followers in developing the Collective memory theory}

Starting from 1970s, we seemed to enter a new period in humanitarian science: there seemed the contemplation of memory to be increased. Many scholars refer to that period as a "memory boom" now. This new epoch in study memory as a social phenomenon began to end since the turn of millennium. How the "story" of memory study began? "Nevertheless, modern perspective on memory and historicity are profound different from much of what came before (though differences are not as absolute and exclusive as they are often portrayed). Part of the change in our view of the past - and of history and memory as ways of framing it - might be characterized as emanating from the triumph not only of the idea of progress but also of the associated "logocentrism" of the Western modernity - the valuation of reason and rationality over other criteria. In terms of memory, this has involved a shift from an emphasis on knowledge from the past about how to do things to an emphasis on knowledge about the past that certain things happened"4.

For our research we used the methodological basis developed by the wellknown French sociologist M. Halbwachs. His work "Les cadres sociaux de la mémoire" ("On collective memory") was published in 1925. He claimed any society has its own collective memory and this type of memory depends upon the "cadre" or framework within which a group that constitutes the society. This fruitful contribution to the sociology was applied to other humanitarian fields such culture study or psychology, theory or history of literature and so on.

According to M. Halbwachs, there exists not only the memory of an individual, but there could be singled out so-called group memory. The last can exist outside of an individual awareness. Thus, an individual's recognition of the society past coincides with this group consciousness of that very past. People express their memory by means of commemoration in their culture. $\mathrm{He}$ insisted the historical memory is a combination of pre-scientific, scientific,

\footnotetext{
${ }^{3}$ Rozdobudko I. (2012) Esli by [I wish]. Kharkiv: Klub simeynogo dozvillya. (in Russain)

${ }^{4}$ Jeffrey K. Olick, Vered Vinitzky-Seroussi, Daniel Levy (2011). The Collective Memory Reader. Oxford University. (in English), P. 8.
} 
quasi-scientific and extra-scientific knowledge and collective representations of a common past. In this reteach, collective memory stands out as an important factor in the social, ethnic, national self-identification of a group and cannot be equated with the official version of history that is treated as an artificially constructed ideological version of the past, its purpose is to manipulate the public mind ${ }^{5}$.

This idea was developed in a number of studies, but they were carried out much later. For example, there has been proved that the basis for such an interpretation of this collective memory concept was the idea that each generation "rewrites" history according to the imperatives of the present to contribute to a better understanding of both the past and the present ${ }^{6}$. A. Kleitman, in "The Age of Commemoration: The Mnemonic Foundations of Socio-Cultural Identity" emphasizes that the remembrance should be understand as "a mirror of our identity and an archive of the truth about us"7.

So, the longing to know the "true past" is an inalienable and essential part of the identity and self-comprehension of any modern society. The phenomenon of commemoration (i.e., the process of memorization - an action, or a ceremony, etc. that makes people remember and show respect for an important person or event in the past) is an important element in the social processes of modern culture $^{8}$. Creation of monuments, museums, determination of outstanding dates, holidays, mass events. According to P. Nora whose name is associated with the new historyo, the mechanism of reactivating the experience of the past is "places of memory", that are socalled sacred objects, architectural structures, events, phenomena, associations, etc. P. Nora has directed "Les Lieux de mémoire" ("The memorial places"), the three volumes work enumerating the places and the objects which could incarnate the national memory of the French people ${ }^{9}$.

One of the most important forms of commemorative activities is the set of historical events and dates that are imprinted in a certain way into the whole nation's collective memory. M. Halbwachs in his work "Collective memory"

${ }^{5}$ Jeffrey K. Olick, Vered Vinitzky-Seroussi, Daniel Levy (2011). The Collective Memory Reader. Oxford University. (in English). P. 140-150.

${ }^{6}$ Kleytman A., Scheglova L. Modusy zabveniya v ontologii kultury [Modes of oblivion in cultural ontology]. Volgograd: FGBOU VPO VAGS. (in Russian)

${ }^{7}$ Kleytman A., Scheglova L. Modusy zabveniya v ontologii kultury [Modes of oblivion in cultural ontology]. Volgograd: FGBOU VPO VAGS. (in Russian)

${ }^{8}$ Vasileva E.O. (2009) Rol praktik kommemoratsii $v$ protsessah organizatsii sotsialnogo prostranstva sovremennogo iskusstva [Commemoration role in the process of modern society space organization]. Vlast, no. 6, pp. 40-43.

${ }^{9}$ Rybalka I.S. (2015) Memory studies sovremennogo ukrainskogo romana. [Memory studies of modern Ukrainian novel] Tomskiy zhurnal lingvisticheskikh $i$ antropologicheskikh issledovaniy. Vol. 3, no. 9, pp. 107-113. 
states: "History divides the sequences of centuries into periods, just as the content of tragedy is divided into several acts. But in a play the same plot is carried from one act to another and the same characters remain true to form to the end, their feelings and emotions developing in an unbroken movement. History, however give the impression that everything - the interplay of the interests, general orientations, modes of studying men and events, traditions, and perspectives on the future - is transformed from one period to another. The apparent persistence of the same groups merely reflects the persistence of external distinctions resulting from places, names, and the general character of the societies. But the individuals composing the same group in two successive periods are like two three stumps that touch at their extremities but do not form one plant because they are not otherwise connected" ${ }^{10}$. Therefore, for collective memory, it is not chronology and eventuality that becomes important, but all that distinguishes one period from another. Since the memories of the significant past events are reflected through the personal experience of each individual and his or her own reality, they are always selective in itself that serves as a kind of demonstration for the actual needs in the society at each certain period ${ }^{11}$.

\section{Fictional text and its commemorative effect on the modern Ukrainian history}

It is doubtless that creating a text can also be called commemoration when it comes to a documentary, scientific or journalistic work. The texts of these kinds are a kind of past eras witnesses and are associated not only with the physical, but also with the virtual culture space. A fiction text can also be treated as one of the forms of expression of the collective and cultural memory, since it bears the imprint of its time (modern scholars emphasize that a fiction text can even be considered as a kind of real documentary $)^{12}$. However, it should be noted that commemoration in this very case meets some artistic interpretation. One should keep in mind that these texts represent the collective memory irrationally. The artist-writer is interested not only in the chronology or sequence of events (and sometimes they do even not care about it at all), but in the feelings and emotions of their characters at this or

${ }^{10}$ Jeffrey K. Olick, Vered Vinitzky-Seroussi, Daniel Levy (2011). The Collective Memory Reader. Oxford University. (in English) P. 143.

${ }^{11}$ Vasileva E. O. (2009) Rol praktik kommemoratsii v protsessah organizatsii sotsialnogo prostranstva sovremennogo iskusstva [Commemoration role in the process of modern society space organization]. Vlast, no. 6, pp. 40-43.

${ }^{12}$ Zverev V. V. (2003) Novyie podhodyi k hudozhestvennoy literature kak istoricheskomu istochniku [New approaches of the fiction as a historical source] Voprosyi istorii, no. 4, pp. 161-166. 
that moment of society development. But still fictional texts are perfect commemorative acts to refresh the emotional and irrational sphere of humankind. The point is that fiction is able to alter the status of memory, because the past of any country (i.e. a state, community, or nation group) is considered as a kind of foreign society not just of the long time ago, but because it is often far away. For example, the rate of immigration has been quite high in the recent fifty years, so reading "right" fictional texts can help the residents of the "the new world" to associate themselves as a part of the old community they try to assimilate in.

After brief considering the basics and the history of "memory studies" we can pass to the discussion of the essential topic of Ukrainian memory and it representation in modern Ukrainian fiction. It seems to be logical to start with historic items. So, there are some very painful periods in Ukrainian history of the XX and XXI centuries defining our collective memory. Among them we can single out the most devastating and ruinous: Holodomor, the Second World War and the present day situation in the East of our country. The first two episodes of our history are well commemorated and widely discussed all over the world to demonstrate to the Communistic regime in the Soviet Union. There horrible and shocking event took place in the first half of the XX centuries. The second part of Soviet Ukraine especially 60s, 70s and 80s are rarely remembered in commemorative practice, except the Chernobyl NPP accident that meet wide commemoration all over the world in the context of environmental protection. Our Soviet history of the second half of the $\mathrm{XX}$ century is full of other less amplitudinous but very important events that as well form our collective memory. These events were either widely adverted all over the USSR or classified. Among the widely adverted ones are Space explorations, Baikal-Amur mainline construction, Olympic Games. The above mentioned achievements demonstrated and stimulated the outstanding raise in economics and politics proving the popular moto of that time "Faster, higher and stronger".

The other events which were highly class and some are still classified might have ruined the image of the Soviet Union as a strong but peace loving state. Here we could enumerate all kind of military conflict happened in any corner of the world of the period. They were everywhere nevertheless they were nowhere. The only conflict that could be discussed open was the civil war in Afghanistan, but the real scale of the Soviet participation in that war was known to a small group of people.

Mentioning the classified reality of that time we are supposed to tackle upon the so-called "defitsit"13 or the lack of the simplest everyday products

\footnotetext{
${ }^{13}$ Lack of something of common use in the USSR: shampoo, sugar, towel etc
} 
and the ordinary people attempt to get these things. These people were treated as criminals and always sentenced to prison. The other very specific crime of that time was desire to utter one's own point of view that was at odd of the general Communistic ideology. They did their best to cope with this kind of unlaws and they also tried to do it secretly.

This list can be continued on and on, but the purpose of our study is not to remember all the painful and ruinous moment in Soviet Ukraine history. We just emphasize that classified information in some certain amount was being spread in the Soviet community. People discussed it in their kitchens in the evening surrounded by very close and reliable friends. This terrifying information was whispered and murmured all over. It was a kind of rumors and gossip - no one could trust it but everybody felt it was true.

All those good and bad moment formulated the collective memory of the present day Ukraine. Understanding the roots of this part of our collective and cultural memory we can explain the current events and transform them for better. We should not only know the bare and objective facts about the events happened but we should reflect those emotions because our irrational and subjective experience influences much on our deeds and actions at the present day. These emotions determine our reaction and decision we make in a lot of situations and the awareness of the emotions can predict and explain our reaction. Here we can also apply the fictional texts on the topics to perceive and realize the emotions and feeling of that time people as it might determine the present day emotional atmosphere. So fiction can be used as a commemorative act to actuate our susceptibility to that kind of feeling.

\section{Irene Rozdobudko's novel "I wish"14 as a commemorative action on Soviet community}

So, here in this abstract, as we have already mentioned, we aim to read and analyze the novel of a talented Ukrainian writer and journalist Iren Rozdobudko to actuate those feeling and emotions. It is supposed it helps in some way to realize the reasons of the current problem in Ukraine. Considering of Iren Rozdobudko's novel "I wish" (2012) in the context of this approach we have tried to determine whether this belles-letres text is part of a collective socio-historical memory. For the researching in this field, the work is perspective, first of all, in terms of its representative capabilities and opportunities. The fantastic plot of time travelling in the past, to be more concrete in 1980, motivates and provokes the detailed description the Soviet community of that time. This allows the author to develop the cultural matrix of the entire Soviet generation, and thus to utter the important problems of the

\footnotetext{
${ }^{14}$ Hereinafter I. Rybalka's translation
} 
modern society. This specification is a certain reflection of the forming the new phenomena of the Ukraine today. Thus, important problems of modern society are highlighted and declared. Thus relevance of our study is obvious both in the context of theory and history of literature as well as in cultural aspect of memory studies ${ }^{15}$.

Iren Rozdobudko graduated from the Kiev National University, journalist department. At the beginning of her carrier she worked as a telegraphist in the Donetsk section of TASS, then she worked at Donetsk Metallurgical Plant newspaper, as a journalist and tried her hand if reading the news at a radio. She moved to Kyiv in 1988, where she worked in the Rodoslav newspaper, as a corrector for the Suchasnist magazine. They invited her as a columnist to the first and third channels of the National Radio Company, a columnist for the Vseukrainsky Vedomosti newspaper, and deputy editor-in-chief in the journal Natalie, the chief editor of Caravan of Stories. Ukraine and a journalist in the journal Academy. She is the author of more than fifteen works that met great recognition among readers. She was awarded with two prizes in literature in 2005 and 2012. She is a screenwriter of seven films as well.

Irene Rozdobudko's creation has already become part of the modern Ukrainian literary process. Her work attracts the attention of both book critics and theorist of literature. Researchers are interested in her ability to create detective stories (N. Galushko, O. Prikhodchenko, L. Starovoit). Some of them conduct detailed study in her characters' psychology (N. Gerasimenko, L. Gorbolis, Yu. Sokolovsky). The gender aspect of her texts also attracts the attention of literary scholars (G. Avksentieva, N. Pavlyuk, K. Tkach). In the contrary, the author's works in the aspect of "Memory studies" have not rarely been touched upon. So here the attempt to have a close look at Irene Rozdobudko's novel "I wish" is made ${ }^{16}$.

To continue discussion of the well-known Ukrainian writer and journalist's novel we should have some brief review of her biography as it may actuate some important items for analyzing the above mentioned work. So Irene Rozdobudko is a representative of a generation that was brought up in "zastoy" time ${ }^{17}$, She witnessed years of "perestroika"18. She continued her

\footnotetext{
${ }^{15}$ Rybalka I.S. (2015) Memory studies sovremennogo ukrainskogo romana. [Memory studies of modern Ukrainian novel] Tomskiy zhurnal lingvisticheskikh $i$ antropologicheskikh issledovaniy. Vol. 3, no. 9, P. 107.

${ }^{16}$ Rybalka I.S. (2015) Memory studies sovremennogo ukrainskogo romana. [Memory studies of modern Ukrainian novel] Tomskiy zhurnal lingvisticheskikh $i$ antropologicheskikh issledovaniy. Vol. 3, no. 9, pp. 107-113.

${ }^{17}$ the period in the Soviet Union history between the middle $60 \mathrm{~s}$ and the beginning of $80 \mathrm{~s}$

${ }^{18}$ the period in the Soviet Union history starting in 1985 and lasting up to the demise of the Soviet Union
} 
carrier as the journalist in the regional newspaper in the first years of independent Ukraine formation. It should be noted that the most of her fictional texts have been written in Ukrainian and Russian, - this makes it possible for more readers to get acquainted with her works as it is very important to read original text. Irene Rozdobudko has not translated her works she has create them in tow languages simultaneously.

The generalized and symbolic depicting of "zastoy" period is the first thing that attracts a reader's pays attention. This period is shown in the novel through the alembic of childhood memories, but at the same time the author describes her past emotions as an adult. After about twenty years the main character Veronika Ivchenko is able to differ between bad and good moments of her young year. Such a binary presentation of the same event enhances the commemorative effect and provokes the reader to review that distant time. So, for example, 1980 was remembered in history as an eventful year: the Olympics, "Subbotnik"19 held all over the USSR in honor of $110^{\text {th }}$ anniversary of Lenin's birth; however, the main character's memory flashes in: “( ... ) Vysotsky died. There was a war in Afghanistan"20.

\section{Reading "I wish" by Iren Rozdobudko as a commemorational text}

As it has already been mentioned, the past events are presented in the novel twice - in memories of a small girl that have survived for years and from tha adult person's point of view. It is often underlined though out the text that very person is a well-experienced and intelligent journalist who knows about the reasons of those events and understands the effects they had for an individual's life and the whole community. It is difficult to overestimate the difference in such interpretations: they acquire a special ideological and aesthetic colouring and provoke deep thinking to realize the changes that met the moral standards.

Commemorative effect of the novel is also enhanced by means of using two types of narrative strategies: the narration is conducted in rotation from the first person and from the third person, while subjectivity of the text is maintained. The reader feels to be inside of the story and, at the same time, has the opportunity to look at it from the outside. The author manages to level the distance between the narrator and the character, which contributes to the cohesiveness of the ideological sphere of the text. It becomes clear that the

\footnotetext{
${ }^{19}$ Voluntary collective work to performance of some socially useful work assignment. The above mentioned event took place in April 1980.

${ }^{20}$ Rozdobudko I. (2012) Esli by [I wish]. Kharkiv: Klub simeynogo dozvillya. (in Russain). P. 63.
} 
internal point of view of the thirty-year-old Veronika Ivchenko ${ }^{21}$, whose childhood passed in the 80s of the last century, is devoted to the complex of ethical and worldview imperatives of a resident of post-Soviet space at the beginning of the 21 st century.

It seems to be necessary to make a brief review of the fantastic plot of the novel. So, the thirty-one journalist, a talented one, by the way, is invited to work on TV. Her ambitions make her try to overcome her oral speech problem. When a child she was frightened by and old pedophile and as a result she stutters when she speaks now. Following the advice of a good specialist she goes to her home block of flats and finds herself in her past. She meets herself in her young years gets acquainted with her parents. She does her best to change her past to prevent some bad moments in her present. At the very end she realizes that her childhood memories are all wrong and her speech problems are caused by her parents' conflict: a seven year girl saw her father with her mother's dear friend when they were having sex in her parents' bedroom. The father reaction on his daughter entering the room was shocking - he hit his child against the wall and that very accident caused her problem with the speech. The main character completely forgot about this event as it was easier for her to believe that she was harmed by a stranger than by her father. Another very important conclusion done by the main character is that her happy Soviet childhood is fiction created by the society.

It is presumptuous to state that the novel presents the reader some factual information about that epoch, but as for the emotional and cultural atmosphere of that time is recreated in the text in a very vivid manner. The binary opposition "pretense / tragic pathos" - this is the framework with which you can describe the events "remembered" by the main character. Thus, the historical antitheses presented in the novel are the following: the Olympic Games - the war in Afghanistan, the anniversary of the birth of Lenin Vysotsky's death, is a peculiar system of moral standards that coordinate Veronica's life. These events are used as a tool for criticizing Soviet realities and emphasize the author's desire not to ignore those "sensitive issues" while interpreting our past.

The topic of exposing our totalitarian past is developed from the main character's subjective perception - everything is described as seen with Veronica's eyes - the only difference makes her age: "' ... >they only knew

${ }^{21}$ The novel is devoted to Veronika Ivchenko. She is the main character, who is successful in her journalistic career, family life. There is only one step left to her triumph on television. The only thing that stops her from her new activity on TV is her problem with oral speech: she stutters. Her psychiatrist advices her to go back to her past in order to live her happy future. So in the process of combating a child's defects, she tries to have a look at difficult childhood and to face the fear. 
about the games because they used to broadcast the Olympic bear with rings on the belt on the screen. I categorically did not like it - it was too flat, big, with a banal smile and with round artificial eyes. From the child's the point of view it was rather unsympathetic"22,23. The objectification of the general event goes gradually and occurs through the secondary characters' utterances "^... >and all the junk people has already been taken a hundred kilometers 〈... it seems to me that this is correct: there is no sense to demonstrate the prostitutes and homeless people to the foreigners" 24,25 ; "I don't know how it was there, but I had seen enough of bribery, theft and total slovenliness ... ( ... . . Unclad walls were poured with white paint to look like done with some white tiles, well, so that the state officials authorized the construction completed. I thought: they'll notice. Far from it! Noticed and accepted"26, 27. The semantic intensity is enhancing against the background of the official interpretation of the events: "July 19, 1980 - the Olympic Games were held in Moscow, they were boycotted by 45 countries <... . The USSR leaders considered these games as an important ideological action. Moscow needed to be demonstrated as a showcase of socialism to the whole world. The idea to boycott the Olympic Games belonged to the Great Britain, Canada and the USA as a protest against the invasion of the Soviet troops in Afghanistan and the persecution of Soviet dissidents" ${ }^{28,29}$. This approach to the presentation of the same event contributes to a certain ironic effect, which is felt literally from the very first mentioning of it.

The Olympic Games pathos is opposed to the real tragedy of the war in Afghanistan - a great number of Soviet people were killed there. It should be noted that in the novel these two historical episodes are mentioned in the general context, but the emotional assessment of this sorrowful page from the Soviet history remains unchanged. "Afghanistan ... From this distant and strange country, which was called "Afghanistan" in the courtyard, at the end of that terrible summer they brought a coffin with the body of Aunt Nina's

\footnotetext{
${ }^{22}$ I. Rybalka's translation.

${ }^{23}$ Rozdobudko I. (2012) Esli by [I wish]. Kharkiv: Klub simeynogo dozvillya. (in Russain).

${ }^{24}$ I. Rybalka's translation.

${ }^{25}$ Rozdobudko I. (2012) Esli by [I wish]. Kharkiv: Klub simeynogo dozvillya. (in Russain).

${ }^{26}$ I. Rybalka's translation.

${ }^{27}$ Rozdobudko I. (2012) Esli by [I wish]. Kharkiv: Klub simeynogo dozvillya. (in Russain).

${ }^{28}$ I. Rybalka's translation.

${ }^{29}$ Rozdobudko I. (2012) Esli by [I wish]. Kharkiv: Klub simeynogo dozvillya. (in Russain).
} P. 63. P. 118 P. 120. P. 63. 
son, and she immediately grew old $\langle\ldots\rangle^{, 30,31}$. Only the ideological perspective varies: "〈 ...〉 we fulfill our ideological duty $\langle\ldots\rangle$. We? Our oughts? Do you owe someone? $\langle.$.$\rangle Our guys die as heroes there! \langle.$.$\rangle But they$ do it for no reasons!" ${ }^{32,33}$.

The current situation declines the necessity for this kind of justification, since five decades completely eliminate this need. M. Halbwachs explains it by the fact when the time passes any society finds new resources and chooses new goals ${ }^{34}$. So the majority of the post-Soviet states have chosen the way of harsh criticism and condemnation of the Soviet period of their history, knowing the results of that senseless war, they do not accept the policy of heroization of the participants of that war, but rather emphasize its senselessness and illegality.

V. Vysotsky's death and the anniversary of "of the world proletariat's leader's" birth are presented within the same vertical of moral standards. The mention of these events in one context provokes the reader to comparative understanding and rethinking of the two episodes, since in the novel these memorable dates received all-Union, national significance: the death of the "singer of sincerity in insincere time" and the birthday of the "leader of the revolution" 35 . "Vysotsky's death almost every person in the block of our flats realized as his or her own - all the day long and everywhere one could hear bad tape recordings of his songs through the windows, which turned into an incredible cacophony. The men nervously smoked and poured some vodka into their glasses under the wooden roofs of the pavilion in our yards"36.

The author recreates this situation to emphasize the absurdity: on the one hand - "incredible cacophony" in memory of the one who could not stand the falsity, and on the other - the "grandiose subbotnik", which united millions not "for the idea", but for "three bottles of vodka": "〈 ... > The fit old man, who had been sleeping and spending his night's on the bench outside, remembered another solemn event - the one hundred and tenth anniversary of Lenin's birth, $\langle\ldots\rangle$ and the grand subbotnik in honor of this event, 150 million people

${ }^{30}$ I. Rybalka's translation.

${ }^{31}$ Rozdobudko I. (2012) Esli by [I wish]. Kharkiv: Klub simeynogo dozvillya. (in Russain). P. 63

${ }^{32}$ I. Rybalka's translation.

${ }^{33}$ Rozdobudko I. (2012) Esli by [I wish]. Kharkiv: Klub simeynogo dozvillya. (in Russain). P. 123.

34 The Collective Memory Reader. Jeffrey K. Olick, Vered Vinitzky-Seroussi, Daniel Levy. Oxford University Press, 2011 - Social Science - 497 pages, - P. 140-147.

${ }^{35}$ Rozdobudko I. (2012) Esli by [I wish]. Kharkiv: Klub simeynogo dozvillya. (in Russain). P. 63.

${ }^{36}$ Rozdobudko I. (2012) Esli by [I wish]. Kharkiv: Klub simeynogo dozvillya. (in Russain). P. 63. 
took part. And he mentioned three bottles of vodka they drove garbage and litter out of the town together with his fellows"37.

The evolution of the main character's attitude towards her present life is obvious, after her "personal meeting" with the Soviet past: "〈... his own suspended animation and indifference is the suspended animation of a whole community of intelligent people who thought "bollocks to that!" about everything around them. They cared just about to stuff with food and clothes their dwelling"38,39. It seems to be important to underline that the main character comes to these conclusions only after she personally succeeds in "meeting the past" in real time. The author stresses in this way that is impossible to perceive those feeling and emotions at the present day. That is why suspended animation of many people today still continues.

The main character's thoughts about the well-known events of that distant 1980 turns into the conclusion: "A human being forgets the bad past very quickly" ${ }^{40,41}$. Researchers of human memory functioning single out three possible causes of the phenomenon to forget ruinous past: philosophical anthropological, sociocultural and psychological ${ }^{42}$. Iren Rozdobudko tends to explain this by the natural protective mechanism by the human mindset: "We only remember the good. Sausage by "rup ${ }^{43}$ and twenty", milk sold in a glass bottle of "twenty two", of course, kopecs ... Absolute calmness and indifference, a pause in the Soviet history called "zastoy" can be found in this passage indicating that 1980 was not chosen by chance. In the fiction world of this text, it acquires the function to project some modern ideas about the USSR as a whole.

The commemorative effect of this novel by Iren Rozdobudko can be clearly seen though comparison of the similar images of the past and the present: "I looked at the shelf. There stood a glass jar of hand cream and a bottle of Bulgarian shampoo "Rose". I grinned: if I want to have a bath normally and wash my hair, you will need to return to the twenty-first

${ }^{37}$ Rozdobudko I. (2012) Esli by [I wish]. Kharkiv: Klub simeynogo dozvillya. (in Russain). P. 212

${ }^{38}$ I. Rybalka's translation.

${ }^{39}$ Rozdobudko I. (2012) Esli by [I wish]. Kharkiv: Klub simeynogo dozvillya. (in Russain). P. 211

${ }^{40}$ I. Rybalka's translation.

${ }^{41}$ Rozdobudko I. (2012) Esli by [I wish]. Kharkiv: Klub simeynogo dozvillya. (in Russain). P. 211.

${ }^{42}$ Kleytman A., Scheglova L. Modusy zabveniya v ontologii kultury [Modes of oblivion in cultural ontology]. Volgograd: FGBOU VPO VAGS. (in Russian)

43 "rup" is short and a bit vulgar for a ruble.

${ }^{44}$ Rozdobudko I. (2012) Esli by [I wish]. Kharkiv: Klub simeynogo dozvillya. (in Russain). P. 212. 
century!"45,46. But latter Veronika feels bitter insight that comes instantly: "After having a bath with avocado oil based foam-cream and washing my hair with some Austrian shampoo that is supposed "to double its volume ", 〈.. 〉 all this seemed so distant and no less strange than this unusual summer. If she could have got all this stuff in a large bag and take them to the place where the smell of Pomorin toothpaste $\langle. .$.$\rangle were the symbols of the child unconditional$ joy If she could throw it all in the middle of a cluttered kitchen and say Look, take it all! This is what you spend your crazy days and hopeless nights wishing and desiring it" ${ }^{, 7,48}$. Destruction of the established axiological system of the main character Veronika Ivchenko leads to her enormous psychoemotional stress: old standards have no values any more, they are ruined - but there are still no new ones! The positive symbolism of the past has lost its semantic meaning, since the character still reinterprets the nature of that "calmness" and "moral perfection". All this happens simultaneously with the awareness of the new moral standards of the present day. Thus, the 1980s are presented as a kind of "disease beginning". Hence today we face only its consequence and continuation ${ }^{49}$.

To sum up everything above mentioned it would be necessary to note that using the "entertaining topic and genre", I. Rozdobudko managed to reveal the causes of moral degradation of the modern society formulated on the postSoviet territory at the beginning of the 21 st century. Commemoration as a structural element of this fiction allows the author to create peculiar "places of memory" and thereby increases the artistic and ideological value of the work: to raise it from the level of an ordinary female novel to the level of intellectual prose. Another theoretical aspect of this very novel touched upon in the text prove the presumption about the usage of the fictional text as a commemorative action worded in the second part of the research seems to be proved.

\section{CONCLUSION}

The so-called "Memory study" is a very popular approach among the scholars to study different aspect of human being life. The thesis uttered by

\footnotetext{
${ }^{45}$ I. Rybalka's translation.

${ }^{46}$ Rozdobudko I. (2012) Esli by [I wish]. Kharkiv: Klub simeynogo dozvillya. (in Russain) P. 90.

${ }^{47}$ I. Rybalka's translation.

${ }^{48}$ Rozdobudko I. (2012) Esli by [I wish]. Kharkiv: Klub simeynogo dozvillya. (in Russain) P. 215.

${ }^{49}$ Rybalka I.S. (2015) Memory studies sovremennogo ukrainskogo romana. [Memory studies of modern Ukrainian novel] Tomskiy zhurnal lingvisticheskikh $i$ antropologicheskikh issledovaniy. Vol. 3, no. 9, pp. 107-113.
} 
the famous French sociologist Maurice Halbwachs in the 1920s allows us to have a close look at the nature of the present day people's mindset.

Thus, in the abstract we tried to analyze the fictional text as a commemoration and to prove that it could possibly be used in commemorative practice. We also have realized the fiction appeals to reader's emotions and feeling and creates the general atmosphere of this or that historical moment rather than stating fact, remembering names of the participants and speaking about its consequents.

The "Memory study" analysis of the novel "I wish" by a well-known Ukrainian writer Iren Rozdobudko actuates the presumption on the commemorative effect of the fiction text. The author manages to fulfill the general atmosphere of the indifference in the Soviet Society in 1980s though the fantastic plot of her novel. This story of some two summer weeks in 1980 retold on behave a thirty-one year old woman who happened to find herself as an adult in her childhood. The main character had an opportunity to influence and change her past as "she wished". This time travelling leads to the main character's understanding the wrong moral standards she had borrowed from her past. Veronica is shocked to realize that her every happy memory from her childhood have nothing to do with that real life. She is supposed to think about some other moral standards to motivate her present life.

Consequently we seem to have proved that commemoration is knitted into the text of the novel as a structural element. It allows the author to work out specific "place of memory" and thereby enlarges the artistic and ideological value of the work: an ordinary female novel turns into a good piece of intellectual prose. Another theoretical aspect of this very novel touched upon in the text prove the presumption about the usage of the fictional text as a commemorative action worded in the second part of the research seems to be proved as well.

\section{SUMMARY}

This abstract studies a novel by famous modern Ukrainian novelist Iren Rozdobudko with the help of the approach worked out by so-called "Memory studies". The use of commemoration in fiction is touched upon as well. Here the analyses of the novel "I wish" written by the famous Ukrainian writer Iren Rozdobudko is presented as a practice of the Soviet Union commemoration. The novel was chosen because of the strong and clear opposition of the past and the present that allows treating it as a kind of "memory place". The work presented can be used as a basis for further analyses of fiction as a type of commemoration.

It's known that one of the most important types of commemorative actions is the use of the dates. The choice of the dates can influence much on the 
perception of the fictional text. Thus Iren Rozdobudko stresses several important and meaningful events of 1980. Among them are the Olympic Games of 1980 and the very beginning of the Afghanistan conflict. These historic events are presented in opposition: a happy one and a sorrowful one. The other two events of 1980 opposed in the text describe cultural reality of that time: the death of Vladimir Vysotskiy and so-called All-Union Subbotnic.

It should be underlined that the author uses no historic names and concrete dates. It contributes to re-creation on the general emotional atmosphere of that time. It appeals to irrational of the reads provoking commemoration of the event described on the other level of perception.

The main character, a thirty-one year old journalist Veronica Ivchenko found herself in 1980. It is the time when she was only seven. She understands everything happened at that period being adult person. It helps her to rethink all the moments and to influence them to change her present. That leads her to understanding that the beginning of the Afghanistan conflict was more important for the people around her than the Olympic Games popularized in the society, the death of famous V. Vysotskiy shocked the community much and people continue remembering him, but nobody remember about the All-Union Subbotnik that was written about in every newspaper and magazine of that time.

We would like to understate that the "entertaining fantastic plot" worked out by Iren Rozdobudko allowed to expose the moral standard degradation of the modern society in the former Soviet Union countries in the early twentyfirst century.

\section{REFERENCES}

1. Kleytman A., Scheglova L. Modusy zabveniya $v$ ontologii kultury [Modes of oblivion in cultural ontology]. Volgograd: FGBOU VPO VAGS. (in Russian)

2. Rozdobudko I. (2012) Esli by [I wish]. Kharkiv: Klub simeynogo dozvillya. (in Russain)

3. Rybalka I.S. (2015) Memory studies sovremennogo ukrainskogo romana. [Memory studies of modern Ukrainian novel] Tomskiy zhurnal lingvisticheskikh $i$ antropologicheskikh issledovaniy. Vol. 3, no. 9, pp. 107-113.

4. Vasileva E. O. (2009) Rol praktik kommemoratsii v protsessah organizatsii sotsialnogo prostranstva sovremennogo iskusstva [Commemoration role in the process of modern society space organization]. Vlast, no. 6, pp. 40-43. 
5. Zverev V. V. (2003) Novyie podhodyi k hudozhestvennoy literature kak istoricheskomu istochniku [New approaches of the fiction as a historical source] Voprosyi istorii. no. 4, pp. 161-166.

6. Jeffrey K. Olick, Vered Vinitzky-Seroussi, Daniel Levy (2011). The Collective Memory Reader. Oxford University. (in English)

\section{Information about the author:}

Iryna Rybalka,

Ph.D in Philology

Assistant Professor of Marine Power Plant

Operation and Maintenance Department

Azov Maritime Institute

National University "Odessa Maritime Academy" 19, Chornomors'ka str., Ukraine, 87517, Mariupol

ORCID ID: ocid.org/0000-0001-6648-7219 